\title{
A collection of functions to determine annual tree carbon increment via stem-analysis
}

\author{
Marco BASCIETTO, Giuseppe ScARASCIA-MugnOZZA* \\ Department of Forest Environment and Resources (DISAFRI), University of Viterbo, Via S. Camillo de Lellis, snc, 01100 Viterbo, Italy
}

(Received 19 June 2003; accepted 6 November 2003)

\begin{abstract}
Stem analysis process is commonly employed in a wide range of applications of forest importance. We developed a program to compute stem increments in terms of volume, biomass and carbon storage. The stem-analysis process involves the felling of the tree, the extraction of a number of cross-sections from the stem and the measuring of ring-width series on each section. The synchronization of ringwidth series provides a number of tree- and stand-related measures including stem growth pattern, diameter at breast height and tree height growth trend, site-index assessment, timber-quality assessment. Relevant features of the program include: (i) tables and charts can be handled in the "R" environment or exported to any spreadsheet program; (ii) algorithms are independent from the ring width measuring device; (iii) the computation of stem volume, yearly- and mean volume increment is provided as well as the lateral surface area, stem carbon pool, its yearlyand mean increment and associated measurement errors. Forest biomass destructive surveys can usefully apply stem-analysis techniques in order to assess forest past carbon increment trend and set up the basis for non-destructive future carbon surveys.
\end{abstract}

stem analysis / carbon pool / annual carbon increment / error budget / R

Résumé - Une compilation de fonctions pour la détermination de l'incrément annuel de carbone à partir de la technique d'analyse de tige. La technique d'analyse de tige est employée communément pour de larges gammes d'applications d'intérêt forestier. Nous avons développé un programme pour calculer l'accroissement de la tige en terme de volume, biomasse et stockage du carbone. La technique d'analyse de tige implique l'abattage de l'arbre, la préparation de nombreuses coupes transversales et la mesure d'une série de largeur de cernes sur chaque section de tige. La synchronisation d'une série de largeur de cernes donne un nombre de mesures corrélées de l'arbre et de la plantation incluant le patron de croissance de la tige, le diamètre à $1,30 \mathrm{~m}$ de hauteur et la tendance de la croissance de l'arbre en hauteur, l'estimation de l'indice de productivité, l'estimation de la qualité du bois. Les caractéristiques importantes du programme incluent : (i) des tables de sortie et des graphiques qui peuvent être gérés dans l'environnement « $\mathrm{R} »$ ou exportés dans une feuille de calcul ; (ii) les algorithmes sont indépendant de l'appareil mesurant la largeur des cernes ; (iii) il fournit le calcul annuel du volume de la tige, du volume moyen produit, et de l'aire de la surface latérale, aussi bien que la biomasse du tige, les stocks de carbone, les incrément annuels, et leurs erreurs associés. Les études de biomasse forestière destructives peuvent appliquer utilement les techniques d'analyse de tige pour estimer rétrospectivement la tendance des incréments de carbone des forêts et la mise au point des bases de futures études non destructives du carbone.

analyse de tige / stock de carbone / incrément annuel de carbone / gestion de l'erreur / $\mathbf{R}$

\section{INTRODUCTION}

The estimation of forest aboveground carbon $(\mathrm{C})$ pools and increments is essential to address the issue of the role of forest ecosystems on the global $\mathrm{C}$ balance $[6,15]$.

Assessment of $\mathrm{C}$ pools and $\mathrm{C}$ increment patterns of trees has to be addressed in order to give an insight on atmospheric $\mathrm{C}$ uptake by forests. A number of direct (on a destructive sampling basis) and non-direct (on increments monitoring grounds) have been put into practise in the past. Destructive biomass samplings can be coupled to stem net primary production measures in order to assess yearly $\mathrm{C}$ increment pattern $[3,9]$.

The stem-analysis technique can be usefully applied to the investigation of $\mathrm{C}$ increment patterns of individual trees. Indi- vidual tree $\mathrm{C}$ patterns can be up-scaled to forest level to finally yield forest growth trend.

A number of computer-based stem analysis programs have been set up in the past $[1,8,12,26,29]$. This paper presents a new stem analysis program. The tReeglia program goal is to provide $\mathrm{C}$ increment trends, yield tables and charts at the tree level, from measures of ring-width on cross sections. The tReeglia program is a collection of open-source functions for the "R" environment (both are available at http://cran.r-project.org). tReeglia key features include:

- Output tables and charts can be written as "comma separated values" files (csv), compatible with widely used spreadsheet programs, such as Microsoft Excel ${ }^{\odot}$. Further, the

* Corresponding author: gscaras@unitus.it 
program works with any ring-width measuring equipment, provided that its output files are converted to csv files.

- Result tables include stem lateral surface area, pool and increment in terms of $\mathrm{C}$ pool, dry-matter wood weight and fresh volume.

- In order to account for the complex architecture of broadleaf trees, stem analysis can be performed on the large branches originating from each fork. tReeglia will build a comprehensive stem analysis table at the tree-level by joining the stem and branches tables.

- The built-in error budget algorithm provides error estimation associated to stem $\mathrm{C}$ and dry-matter wood weight taking into account wood volume coefficient uncertainty, wood C content uncertainty and wood density uncertainty.

- The program is distributed under the GPL licence, its source code can be modified by anyone and redistributed under the same licence.

\section{STEM ANALYSIS ALGORITHMS}

\subsection{Volume correction}

Wood is a hygroscopic material, hence its water content depends on the temperature and humidity content of the air. Ring-widths are usually measured at room mean temperature and humidity. Measures of the reduction of volume from the wet-state to the room mean temperature and humidity state, should be carried out on a number of test cross-sections. The mean coefficient and its standard error will be used to expand the computed stem volume to fresh volume.

If wood volume coefficients are not purposely measured, one should refer to the list of species-specific volume coefficient values in Appendix B [24]. The list provides oven-dry wood $\left(V_{D}\right)$ to fresh-wood $(V)$ volume coefficients $\left(S_{V}\right)$ for several forestrelevant species $\left(S_{V}=V / V_{D}\right)$. To avoid inconsistencies due to dependency of data, $S_{V}$ should be measured on an independent set of cross-sections. If radial increments are measured on cross-sections equilibrated to mean room temperature and humidity, the appendix coefficients should to be halved [14] $\left(S_{V}=\left(S_{V}-1\right) / 2+1\right)$.

\subsection{Height/age algorithm}

Considering any two sections on a tree, typically the upper one contains fewer rings than the lower one. This means that it took the tree a number of years equal to the difference in number of rings to grow up from the lower cross-section level to the upper one level. Geometrically each missing ring outlines an hidden cone whose tip lies within the log and whose base is formed by the ring itself. It is important to estimate tree upward movement between any two cross-sections in order to calculate the volume of each hidden cone.

A number of authors have proposed height interpolation algorithms (e.g. [7, 10, 20, 22, 25]). Upon comparison of five tree height interpolation procedures to actual tree heights, it has pointed out that residuals of Carmean corrected heights are very low [11]. As a result the program has implemented Carmean algorithms to address the height/age issue.

Carmean algorithm includes a set of three equations. It is applied on each log within any two cross-sections and looped as many times as the number of missing rings on the upper cross-section. The equation range of applicability depends on $\log$ location [11]. Carmean's equations assume that:

- On the average, the annual height increment is equal for each year lying within the log.

- The cross-section height will occur in the middle of the annual leader.

The second assumption imposes a strong methodical bond to height correction computation. Although Carmean's algorithm is based on arbitrary assumption, it yields the best results when it comes to height increment on $2 \mathrm{~m}$ longer logs [11].

\subsection{Increment trend algorithms}

The increment computation is a classic analysis in forestry. The equations adopted by tReeglia assume that tree profile can be identified by an Apollonius paraboloid [19]. The program employs the trapezium formula to measure stem volume $(V)$.

Let the basal area of a section of radius $w$ be:

$$
G=\pi \cdot w^{2} .
$$

The volume of the individual logs enclosed between the $i$ th and the $(i+1)$ th cross-section is computed through Smalian's formula (also known as the formula of the mean section):

$$
v_{i}=\frac{G_{i}+G_{i+1}}{2} \cdot\left(h_{i+1}-h_{i}\right) .
$$

Stem volume $(V)$ is calculated as the sum of each log volume and the volume of the cone formed by tree terminal bud and the highest cross-section:

$$
V=\sum_{i=1}^{n} v_{i}+\frac{G_{n}}{3} \cdot\left(h_{\text {tree }}-h_{n}\right) .
$$

Equations (1) and (2) are looped for each year of tree life to yield annual stem volume. Annual volume increments $\left(I_{y}\right)$ are computed by subtraction of subsequent volume pools: $I_{y}=V_{y}-V_{y-1}$.

The volume coefficient $\left(S_{V}\right)$ is applied to $V$ and to $I_{y}$ to yield estimates of fresh volume and annual fresh volume increments.

The dry-matter wood weight $\left(W_{w}\right)$ is computed multiplying stem volume by the volume coefficient and by wood basic density $\left(D_{w}\right)$. Annual increments of dry-matter wood weight are computed applying a similar equation to $I_{y}$.

Stem $\mathrm{C}$ pool $\left(W_{C}\right)$ is calculated by multiplying stem volume by the volume coefficient, by wood basic density and by the ratio of carbon to dry-matter wood weight $\left(R_{C}\right): W_{C}=V \cdot S_{V}$. $D_{w} \cdot R_{C}$. This equation is applied to $I_{y}$ to provide annual $\mathrm{C}$ increments.

The lateral surface area of the individual logs enclosed by each cross-section $\left(a_{i}\right)$ is computed assuming that logs follow the profile of a paraboloid of Apollonius: $a_{i}=\pi \cdot\left(w_{i}+w_{i+1}\right)$. $\left(h_{i+1}-h_{i}\right)$.

Stem lateral surface area $(A)$ is calculated as the sum of each $\log$ lateral area and the lateral area of the cone formed by tree tip:

$$
A=\sum_{i=1}^{n} a_{i}+\pi \cdot w_{n} \sqrt{w_{n}^{2}+\left(h_{\text {tree }}-h_{n}\right)^{2}} .
$$


Table I. Stand forest parameters for the year 2000 (Mund 2001, pers. comm.)

\begin{tabular}{lcccc}
\hline & $\begin{array}{c}\text { Tree density } \\
\left(\text { tree ha }{ }^{-1}\right)\end{array}$ & $\begin{array}{c}\text { Basal area } \\
\left(\mathrm{m}^{2} \mathrm{ha}^{-1}\right)\end{array}$ & $\begin{array}{c}\text { Mean } \\
\text { diameter }(\mathrm{cm})\end{array}$ & $\begin{array}{c}\text { Dominant } \\
\text { height }(\mathrm{m})\end{array}$ \\
\hline Beech & 2976 & 12 & 7.0 & 13 \\
Ash and maple & 1792 & 6.6 & 7.0 & 13 \\
\hline
\end{tabular}

\subsection{Error budget algorithm}

Estimation errors affect either stem fresh volume, dry-matter wood weight and C pool. tReeglia error budget algorithm takes into account the bias introduced by the volume coefficient, the basic density and the wood $\mathrm{C}$ ratio.

The standard errors of volume coefficient, basic density and wood $\mathrm{C}$ ratio are combined using the standard formula of multiplicative error propagation for variables with uncorrelated variances:

$$
\operatorname{se}\left(W_{C}\right)=W_{C} \cdot \sqrt{\left(\frac{\operatorname{se}\left(S_{V}\right)}{S_{V}}\right)^{2}+\left(\frac{\operatorname{se}\left(D_{W}\right)}{D_{W}}\right)^{2}+\left(\frac{\operatorname{se}\left(R_{C}\right)}{R_{C}}\right)^{2}} .
$$

\section{ASSESSMENT OF ABOVEGROUND C INCREMENT IN A BEECH STAND}

\subsection{Materials and methods}

The aboveground $\mathrm{C}$ pool and the increment of a 30 -years old mixed broadleaf stand was estimated for year 2000. The site is located in Thüringen, Germany $\left(51^{\circ} 20^{\prime} \mathrm{N}, 10^{\circ} 22^{\prime} \mathrm{E}\right)$. It is an early stage of a well-established even-aged forest chronosequence.

The forest lies at $430 \mathrm{~m}$ a.s.1, mean annual precipitation is $750-800 \mathrm{~mm}$ and mean annual temperature is $6.5-7.0^{\circ} \mathrm{C}$. The forest soil is a very uniform, fertile, silty, clay loam brown luvisol.

The forest (Tab. I) is dominated by European beech (Fagus sylvatica L.) with presence of Ash (Fraxinus excelsior L.) and maple (Acer pseudoplatanus L.). Twelve beech trees, and 10 ash trees were felled in May 2001. Increment cross-sections were taken along the stem at $1 \mathrm{~m}$ intervals. Wood density was measured on two further cross-section per each tree. Increment cross-sections were stored in a fresh air-drying chamber and sanded a few months later before ring width measurements were carried out. Radial increment measurements were made to the nearest $0.0025 \mathrm{~mm}$ on two radii on each of the cross-sections, using the LINTAB measurement equipment (Frank Rinn, Heidelberg, Germany) fitted with a Leica MS5 stereomicroscope and analysed with the TSAP software package. The time series were averaged into a mean stand chronology and synchrony was checked by means of Pearson's $r$ correlation coefficient and Student's $t$-test, to determine the significance of the $r$-value $\left(H_{0}: r \neq 0, \alpha_{2}=0.05\right)$.

Wood density was calculated as the ratio of dry weight over dry volume. Wood samples were oven-dried at $80{ }^{\circ} \mathrm{C}$ to constant weight. Wood volume was measured by water displacement to the nearest $10 \mathrm{~mL}$, wood weight was measured to the nearest $0.01 \mathrm{~g}$.

Stem analysis was performed on each stem using the tReeglia program to compute stem $\mathrm{C}$ increment. Wood basic density

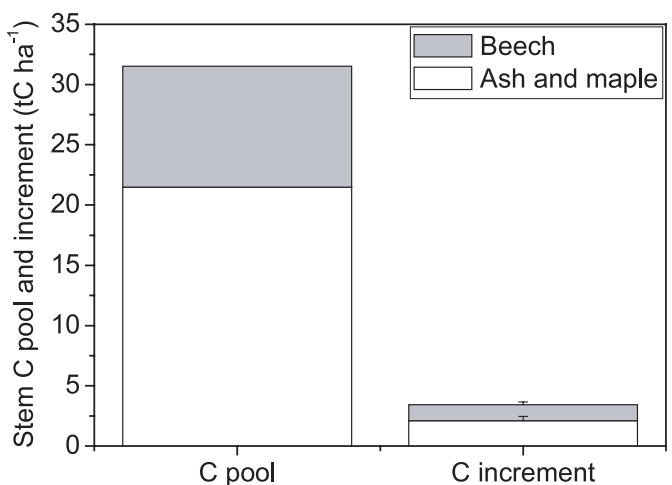

Figure 1. Stem $\mathrm{C}$ pool and increment at the stand scale of the 30 years-old mixed broadleaf forest.

was calculated as the ratio of dry weight over fresh volume. Carbon to dry wood weight ratio was used to convert stem wood dry weight to $\mathrm{C}$ pool. Three stem subsamples per tree were analyzed for $\mathrm{C}$ content. Beech and ash wood volume coefficients from Appendix B were used.

A one-stage Randomised Branching Sampling (RBS) was used to upscale stem $\mathrm{C}$ increments to the stand-level $[3,17]$.

\subsection{Results and discussion}

Stem lateral surface area, $\mathrm{C}$ pool, and their increments were computed for the 22 sampled trees (Tab. II). The age of the sampled trees varied greatly, three clusters can be clearly identified according to their age. The oldest trees range from 48 to 59 yearold $(n=5)$, the middle-aged trees range from 29 to $34(n=10)$, the youngest trees range from 21 to 25 year-old $(n=7)$. The age clustering is a result of the shelterwood cuttings. It is interesting to note that ash trees are represented in all three age clusters, indicating a slow regeneration rate, alongside the beech renovation.

The $\mathrm{C}$ pool showed great variation among the sampled trees, although a weakly significant $\left(H_{0}: r \neq 0, \alpha_{2}=0.08\right)$ linear correlation is shown against age $(r=0.39)$. Despite this, the tree $\mathrm{C}$ increment seems not to be related to age ( $r$ not significantly different from 0 ), and is weakly exponentially related to tree diameter at breast height [21]. The high variability showed by the sampled trees is probably due to a long regeneration period given to the prior old-growth forest, lasting from the seeding cut to the last cut of the old-growth trees.

Estimated errors associated to $\mathrm{C}$ pool and increment are directly related to the variability of the density and $\mathrm{C}$ content estimates of wood of the sampled trees. The relative contribution of the error to stem $\mathrm{C}$ pool or increment range from $0.67 \%$ (tree 7 ), to $25 \%$ (tree I), being $7.9 \%$ on average. In this case, the major contributor to $\mathrm{C}$ increment error was the variability of the wood density measures. As a result, it is shown that uncertainties can significantly affect $\mathrm{C}$ pool and increment estimates at the tree-scale.

Stem $C$ increment at the stand level ( \pm 1 S.E.) reached $3.44 \pm$ $0.428 \mathrm{tC} \mathrm{ha}^{-1} \mathrm{yr}^{-1}$ (Fig. 1), the $\mathrm{C}$ pool was $31.5 \mathrm{tC} \mathrm{ha}^{-1}$ (Hajny M.T., pers. com.). Other authors claimed higher pools and increments for beech forest of comparable ages. The dry matter 
Table II. Cambial age, C pool and increment of the sampled trees in the mixed broadleaf stand, as for year 2000. Arabic numbers indicate beech trees, letters mark ash trees, "ste" is standard error. The standard error does not take into account the volume coefficient error.

\begin{tabular}{|c|c|c|c|c|c|}
\hline Sample tree & Cambial age & C pool $(\mathrm{kgC})$ & C pool ste $(\mathrm{kgC})$ & 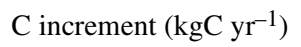 & $\mathrm{C}$ increment ste $\left({\left.\mathrm{kgC} \mathrm{yr}^{-1}\right)}^{-1}\right.$ \\
\hline 1 & 33 & 31 & 0.86 & 4.2 & 0.12 \\
\hline 2 & 33 & 8.6 & 0.24 & 1.0 & 0.03 \\
\hline 3 & 26 & 40 & 3.5 & 4.9 & 0.43 \\
\hline 4 & 34 & 16 & 1.5 & 1.6 & 0.15 \\
\hline 5 & 24 & 19 & 0.38 & 2.3 & 0.05 \\
\hline 6 & 59 & 19 & 0.93 & 2.6 & 0.12 \\
\hline 7 & 30 & 24 & 0.16 & 3.5 & 0.02 \\
\hline 8 & 55 & 92 & 3.5 & 6.5 & 0.25 \\
\hline 9 & 25 & 1.8 & 0.06 & 0.06 & 0.00 \\
\hline 10 & 48 & 14 & 0.16 & 0.10 & 0.00 \\
\hline 11 & 58 & 21 & 0.48 & 0.17 & 0.00 \\
\hline 12 & 29 & 3.4 & 0.27 & 0.14 & 0.01 \\
\hline A & 21 & 4.1 & 0.46 & 0.63 & 0.07 \\
\hline B & 21 & 2.5 & 0.38 & 0.30 & 0.05 \\
\hline $\mathrm{C}$ & 21 & 24 & 3.1 & 3.3 & 0.43 \\
\hline D & 21 & 17 & 1.0 & 2.2 & 0.13 \\
\hline E & 33 & 21 & 4.9 & 1.1 & 0.26 \\
\hline $\mathrm{F}$ & 33 & 21 & 1.2 & 1.1 & 0.07 \\
\hline $\mathrm{G}$ & 56 & 19 & 0.99 & 0.45 & 0.02 \\
\hline $\mathrm{H}$ & 36 & 11 & 1.4 & 0.57 & 0.07 \\
\hline I & 33 & 6.3 & 1.6 & 0.41 & 0.10 \\
\hline $\mathrm{L}$ & 32 & 15 & 0.84 & 1.1 & 0.06 \\
\hline
\end{tabular}

pool of a 38-41 years-old forest was reported to be $165 \mathrm{t} \mathrm{ha}^{-1}$ [2], while the pool of a 35 years-old forest was $121 \mathrm{t} \mathrm{ha}^{-1}$ [5]. Converting both pools to $\mathrm{C}$ pools, assuming a $\mathrm{C}$ ratio of 0.48 , the $\mathrm{C}$ pool of the Thüringen forest is very low. The low pool is paralleled by a low increment upon comparison with a 30 yearsold beech stand [16] reporting a Net Primary Productivity of $5.22 \mathrm{tC} \mathrm{ha}^{-1} \mathrm{yr}^{-1}$ for the year 1997. These results may point to a low site fertility or to a lack of proper forest management in the Thüringen stand.

\section{AN INCREMENT CORE TO ASSESS STEM C POOL}

\subsection{Conceptual framework}

The following example uses tReeglia to compute total tree $\mathrm{C}$ pool at year of felling. In even-aged stands stem $\mathrm{C}$ pool can be modeled as a function of tree radius and its age. Conifer wood density can be a good proxy of radial increment $[4,18$, 27]. They are in fact negatively correlated i.e. higher ring wood densities $\left(D_{R}\right)$ are associated to smaller radial increments $\left(W_{R}\right)$ : $D_{R} \alpha W_{R}^{-1}$. Evidences of this inverse relationship for Norway spruce have been claimed in different thinning experiments $[23,28]$. However, it should be noted that ring width and its maximum density are also influenced by climatic variability [13].

In trees of same-age, radial increments at any height are positively correlated to stem volume and stem $\mathrm{C}$ pool, although the proportionality may vary from year-to-year. As a result, we theorize that wood density is negatively correlated to stem $\mathrm{C}$ pool on same-age trees. In any radial section along a tree-stem, if wood density $\left(D_{W}\right)$ along the whole section approximates mean wood density of the individual rings $\left(D_{W} \cong \bar{D}_{R}\right)$ then:

$$
D_{W} \alpha \frac{1}{\sum W_{R}} \text {. }
$$

Being a three-dimensional solid, stem volume is proportional to the squared ring width and to tree height: $V \alpha\left(\sum W_{R}\right)^{2} \cdot h_{\text {tree }}$, hence: $\sum W_{R} \alpha \sqrt{V / h_{\text {tree }}}$. From (3): $D_{W} \alpha \frac{1}{\sqrt{V / h_{\text {tree }}}}$, hence:

$$
V \alpha \frac{h_{\text {tree }}}{D_{W}^{2}} .
$$




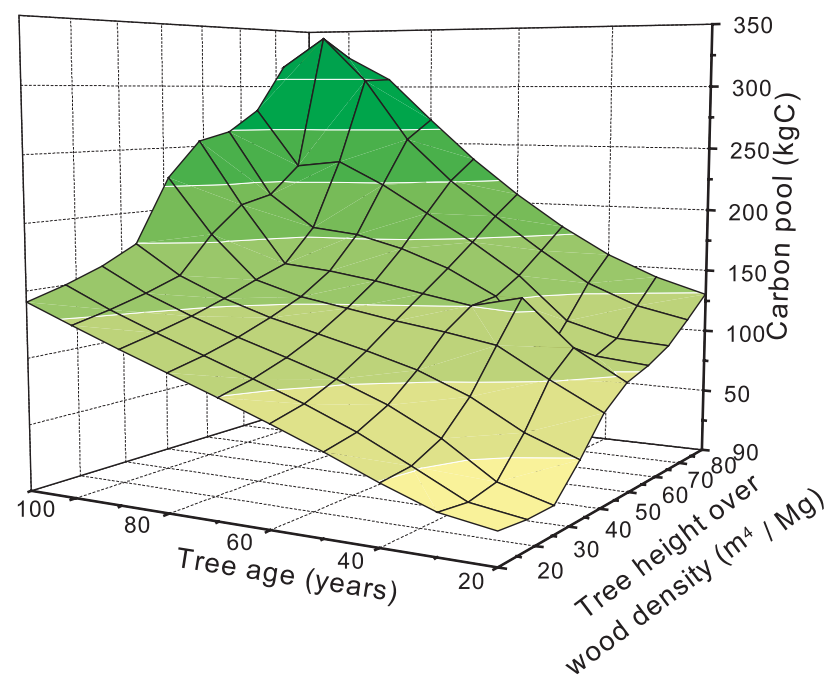

Figure 2. Stem C pool trend in Picea abies (L.) Karst. even-aged stands. Tree age, height and wood density can be good proxies of stem $\mathrm{C}$ pool in conifer even-aged stands.

On the contrary, from the definition of $W_{C}$, assuming $R_{C}$ and $S_{V}$ as constants, the volume is proportional to the ratio between $\mathrm{C}$ pool and wood density: $V \propto W_{C} / D_{W}$. Substituting it in (4): $W_{C} / D_{W} \alpha h_{\text {tree }} / D_{W}^{2}$ and finally:

$$
W_{C} \alpha \frac{h_{\text {tree }}}{D_{W}}
$$

Equation (5) expresses the positive correlation between stem $\mathrm{C}$ pool and the ratio tree-length over wood density in conifer trees of same age. This relationship could be used in order to assess stem $\mathrm{C}$ pool and $\mathrm{C}$ increment through a non-destructive direct sampling. This could be simply done by measuring the height of sample trees, extracting an increment core at stump height, measuring its dry-matter wood density and counting its rings to determine the tree age.

\subsection{Materials and methods}

26 spruce (Picea abies (L.) Karst.) trees were felled in four spruce even-aged stands in the Tharandt Wald (Saxony, Germany, $50^{\circ} 56^{\prime} \mathrm{N} ; 13^{\circ} 28^{\prime} \mathrm{E}$ ). The stands lie in a narrow, gently sloping area, and share the same soil and continental climate features. Annual precipitation is $820 \mathrm{~mm}$, mean annual air temperature is $7.5^{\circ} \mathrm{C}$.

Increment cross-section were taken along the stem at $2.5 \mathrm{~m}$ intervals. Further, basic density was measured on three crosssections per each tree. Increment cross-sections, wood density and $\mathrm{C}$ content were analysed as for the broadleaf forest case study.

\subsection{Model validation}

Stem C pool, dry-matter wood density, tree age and length data sets were recorded per each tree. The 26 data sets were plotted in a 3-dimensional plot (Fig. 2). Figure 2 substantiates the positive correlation between stem $\mathrm{C}$ pool and tree height over wood density ratio. At any given tree age, stem $\mathrm{C}$ pool increases as the ratio of height over wood density increases. The $\mathrm{C}$ pool and height over density ratio variables seem to be strongly correlated. As a matter of facts, denser-wood stems allocate more $\mathrm{C}$ (at same-age) and, presumably, will yield better merchantable timber. However, a number of approximations have been involved to achieve equation (5), and it should be validated more extensively.

Wood density assay in conifer plantations could be a good gauge for forest management decisions, as far as thinning practices are concerned. If high mean wood density is desired, trees with high growth rates should be harvested early in thinning operations [4].

Acknowledgments: We would like to thank A. Masci (University of Viterbo) for useful advice on forest management and forest growth pattern issues, and M. Gaudet for the french translation. This research has been supported by the EU FORCAST project (contract No. EVK2-CT-1999-00035).

\section{APPENDIX A. Index to equation symbols}

\begin{tabular}{|c|c|}
\hline$i:$ & Cross-section increment number \\
\hline$n:$ & Number of boles enclosed by the $n$ cross-sections \\
\hline$h_{\text {tree }}:$ & Stem length at current year \\
\hline$v_{i}:$ & Volume of $i$-th $\log$ \\
\hline$w_{i}$ : & Radius of the current-year lower cross-section \\
\hline$w_{i+1}:$ & Radius of the current-year upper cross-section \\
\hline$w_{n}:$ & Radius of the highest cross-section at current-year \\
\hline$G_{i}$ & Basal area of the current-year lower cross-section \\
\hline$G_{i+1}:$ & Basal area of the current-year upper cross-section \\
\hline$G_{n}:$ & Basal area of the highest cross-section at current-year \\
\hline$h_{i}$ : & Height of the lower cross-section \\
\hline$h_{i+1}$ & Height of the upper cross-section \\
\hline$h_{n}:$ & Height of the highest cross-section \\
\hline$y:$ & $\begin{array}{l}\text { Any cambial age in the range from } 0 \text { to tree age at time } \\
\text { of sampling }\end{array}$ \\
\hline$W_{C}:$ & Stem C pool \\
\hline$S_{V}$ & Volume coefficient \\
\hline$D_{W}:$ & Stemwood basic density \\
\hline$R_{C}$ & Carbon to dry-matter wood ratio \\
\hline$V:$ & Fresh stem volume \\
\hline$V_{D}:$ & Oven-dry stem volume \\
\hline $\operatorname{se}():$ & Standard error \\
\hline$D_{R}$ & Tree-ring density \\
\hline$W_{R}:$ & Tree-ring width \\
\hline
\end{tabular}




\section{APPENDIX B. Volume coefficients from oven-dry wood to fresh wood}

$\begin{array}{lc}\text { Species } & \text { Volume coefficient } \\ \text { Abies alba Mill. } & 1.110 \\ \text { Alnus glutinosa Gaertn. } & 1.114 \\ \text { Carpinus betulus } \text { L. } & 1.230 \\ \text { Castanea sativa Mill. } & 1.112 \\ \text { Cupressus sempervirens } \text { L. } & 1.104 \\ \text { Fagus sylvatica } \text { L. } & 1.170 \\ \text { Fraxinus excelsior } \text { L. } & 1.142 \\ \text { Juglans regia } \text { L. } & 1.130 \\ \text { Larix decidua } \text { Mill. } & 1.138 \\ \text { Ostrya carpinifolia } \text { Scop. } & 1.230 \\ \text { Picea abies } \text { (L.) Karst. } & 1.127 \\ \text { Pinus nigra } \text { Arn. s.l. } & 1.124 \\ \text { Pinus pinea } \text { L. } & 1.108 \\ \text { Pinus sylvestris } \text { L. } & 1.130 \\ \text { Platanus } \text { orientalis } \text { L. } & 1.126 \\ \text { Populus } \text { sp. pl. } & 1.098 \\ \text { Pseudotsuga } \text { sp. pl. } & 1.142 \\ \text { Quercus cerris L. } & 1.192 \\ \text { Quercus petraea } \text { (Matt.) Liebl. } & 1.132 \\ \text { Quercus robur } \text { L. } & 1.132 \\ \text { Robinia pseudoacacia } \text { L. } & 1.142 \\ \text { Tilia } \text { sp. pl. } & 1.150 \\ \text { Ulmus } \text { sp. pl. } & 1.138 \\ & \end{array}$

\section{REFERENCES}

[1] Alia R., Ipinza R., Roldan M., Fustin-programa para analisis de tallo para el estudio del crecimiento de arboles individuales, Ecologia 2 (1988) 139-153.

[2] Bartelink H.H., Allometric relationships for biomass and leaf area of beech (Fagus sylvatica L.), Ann. Sci. For. 54 (1997) 39-50.

[3] Bascietto M., Cherubini P., Scarascia-Mugnozza G., Tree rings from a European beech (Fagus sylvatica) forest chronosequence are useful for detecting growth trends and carbon sequestration, Can. J. For. Res. 34 (2004) 481-492.

[4] Bergqvist G., Wood density traits in Norway spruce understorey: effects of growth rate and birch shelterwood density, Ann. Sci. For 55 (1998) 809-821.

[5] Calamini G., Gregori E., Produzione fogliare in un giovane popolamento di faggio (Fagus sylvatica L.) dell'Appennino Pistoiese, in Atti del seminario funzionalità del sistema faggeta, Accademia Italiana di Scienze Forestali, 1995, pp. 309-318.

[6] Carey E., Sala A., Keane R., Callaway R.M., Are old forests underestimated as global carbon sinks? Glob. Change Biol. 7 (2001) 339-344.

[7] Carmean W.H., Site index curves for Upland Oaks in the Central States, For. Sci. 18 (1972) 109-120.

[8] Cho E.H., A computer program for stem analysis, J. Korean For. Soc. 69 (1985) 6-12.

[9] Clark D.A., Brown S., Kicklighter D.W., Chambers J.Q., Thomlinson J.R., Ni J., Measuring net primary production in forests: concepts and field methods, Ecol. Appl. 11 (2001) 356-370.
[10] Dyer M.E., Bailey R.L., A test of six methods for estimating true heights from stem analysis data, For. Sci. 33 (1987) 3-13.

[11] Fabbio G., Frattegiani M., Manetti M.C., Il metodo di analisi del fusto. Confronto tra cinque metodi di stima della relazione altezzaetà, Annali dell'Istituto Sperimentale per la Selvicoltura, Arezzo 19 (1988) 117-154.

[12] Frattegiani M., Ghetti S., Manetti M.C., Programma per l'analisi del fusto "ANAFUS2", Annali dell'Istituto Sperimentale per la Selvicoltura, Arezzo 19 (1988) 177-188.

[13] Gindl W., Grabner M., Wimmer R., The influence of temperature on latewood lignin content in treeline Norway spruce compared with maximum density and ring width, Trees 14 (2000) 409-414.

[14] Giordano G., Variazioni della densità del legno, in: Tecnologia del legno, Vol. 1, UTET, Torino, Italy, 1971, pp. 832-869.

[15] Goodale C.L., Apps M.J., Birdsey R.A., Field C.B., Heath L.S., Houghton R.A., Jenkins J.C., Kohlmaier G.H., Kurz W., Liu S., Nabuurs G.-J., Nilsson S., Shvidenko A.Z., Forest carbon sinks in the northern hemisphere, Ecol. Appl. 12 (2002) 891-899.

[16] Granier A., Ceschia E., Damesin C., Dufrêne E., Epron D., Gross P., Lebaube S., Le Dantec V., Le Goff N., Lemoine D., Lucot E., Ottorini J.-M., Pontailler J.Y., Saugier B., The carbon balance of a young beech forest, Funct. Ecol. 14 (2000) 312-325.

[17] Gregoire T.G., Valentine H.T., Furnival G.M., Sampling methods to estimate foliage and other characteristics of individual trees, Ecology 76 (1995) 1181-1194.

[18] Klemm G.G., Effect of planting space on the quality of spruce wood and sulphite pulp, Commun. Norwegian For. Res. Inst. 28 (1942) 257-293.

[19] La Marca O., Elementi di Dendrometria, Patron Editore, Bologna, Italy, 1999.

[20] Lenhart J.D., An alternative procedure for improving height/age data from stem analysis, For. Sci. 18 (1972) 332.

[21] Masci A., Hajny M.T., Bascietto M., Matteucci G., Biomassa epigea in una cronosequenza di faggio della Turingia (Germania), in Alberi e Foreste per il nuovo Millennio, Proceedings of the third meeting of the Italian Society of Forest Management and Ecology (SISEF), 2003.

[22] Monserud R.A., Height growth and site index curves for inland Douglas fir based on stem analysis data and forest habitat type, For. Sci. 30 (1984) 943-965.

[23] Mörling T., Evaluation of annual ring width and ring density development following fertilisation and thinning of Scots pine, Ann. For. Sci. 59 (2002) 29-40.

[24] Nardi Berti R., La struttura anatomica del legno ed il riconoscimento dei legnami italiani di più comune impiego, Contributi Scientifico-Pratici per una migliore conoscenza ed utilizzazione del legno, CNR 24 (1979) 117-155.

[25] Newberry J.D., Dominant height growth models and site index curves for site-prepared Slash pine plantations in the lower coastal plain of Georgia and North Florida, M.S. thesis, University of Georgia, USA, 1978, pp. 1-47.

[26] Newton P.F., Stem analysis program for coniferous forest tree species, Comput. Electron. Agric. 39 (2003) 61-66.

[27] Olesen P.O., The interrelation between basic density and ring with of Norway spruce, Danish For. Res. Inst. 34 (1976) 341-359.

[28] Pape R., Effects of thinning regime on the wood properties and stem quality of Picea abies, Scand. J. For. Res. 14 (1999) 38-50.

[29] Timmer V.R., Verch B.R., SAPP: a computer program for plotting stem analysis, For. Chron. 59 (1983) 298-303. 